the temperature is accurately recorded both immediately before and after passing the crystal, the authors hare been able to prore definitely that the temperature at which gypsum becomes uniaxial is for sodium light $91^{\circ}$, for red $\mathrm{C}$ and greenish-blue $\mathrm{F}$ hydrogen light $89^{\circ}$, and for the violet hydrogen line near $G 87^{\circ}$. 'These temperatures agree precisely with those observed for the exact superposition of the pair of images of the spectrometer slit, afforded by a $60^{\circ}$ prism cut to give the $a$ and $\beta$ refractive indices. Owing to the large correction necessary for conduction of the crystal holder when the ordinary Fuess air-bath heating apparatus was employed, and to the difficulty in determining it, former determinations of the temperature at which a section-plate of gypsum becomes uniaxial were too high, and did not agree with the prism observations.-Dr. G. F. H. Smith : Note on a large Crystal of Anatase from the Binnental. The crystal exhibits a combination of the forms $a(100), \tau(313)$, and $z(113)$, and the others not prominent, and it is remarkable for the fact that the faces $\tau$ have been entirely replaced by numberless tiny crystals with the forms $z(113), k(112), p(111)$, and $e(101)$, and the same orientation as the large crystal.

\title{
CORRESPONDENOE.
}

\section{THE DRAWING ON A RED CRAG SHELL.}

SrR,-I think we shall do well to be cautious in recognizing a "long-lost brother" in the Red Crag, though his credentials have been accepted by no less an authority than Sir E. Ray Lankester. At any rate $I$ doubt whether the carving on a shell of Pectunculus glycimeris, eited in your last number by Dr. M. C. Stopes, strengthens the evidence in favour of his existence. I had the opportunity of examining this a few years ago and possess a photograph, which Mrs. Stopes kindly gave me at that time. The design and execution of the engraring reminded me rather of a piece of grotesque, dating from the nineteenth century, than of the efforts of Palæolithic man, as displayed on the walls of caves or in other relics of his handywork. That, howerer, is a matter of opinion, but what weighed even more with me when I examined the specimen was the state of the shell and the carvings. The former, especially its hinge-teeth, showed the very slight corrosion usual in Crag specimens of this Pectunculus, while the surface of the carved parts was smooth and comparatively freshlooking. I do not doubt that the late Mr. Stopes was convinced that he had obtained possession of a genuine relic of Red Crag Man, but, if we could trace out the history of the specimen before it came in to his hands, I think we should find this another instance of an "old friend with a new face".

T. G. Bonner.

\section{STRATIGRAPHICAT NAMES.}

SIR,-It is probable that few geologists whose studies are limited to a single country, or even to a single continent, have any adequate conception of the large number of names that have been proposed either for geological formations or for periods of geological time. 
I do not myself know how many such names there are, but my cardindex to them, incomplete though it unfortunately is, already extends to a thickness of over two yards. From this simple fact certain consequences follow.

In the first place it is impossible for those of us who have to deal with formations of every age and from all quarters of the globe to carry in our heads the numerous names that have been proposed for them. A card-index, such as that to which I have referred, is an almost indispensable aid to one's work, and it is very necessary to keep it up to date. But since few workers possess such a card-index, there is an erer-increasing chance that those names which are yearly, one might say daily, proposed, will be already utilized in some other sense. New names continue to appear in all languages and in publications of most diverse standing, including many that have an extremely limited and local circulation. And just as there is no restriction on the part of publications, neither does there seem to be any on the part of the worker who thinks himself entitled to propose such new names. Not only are they proposed by recognized official bodies, such as national surveys, but also by individual geologists of every degree of competence. Thus, the chances that the names will be unsuitable at the outset and overlooked afterwards are greatly increased.

To give one or two examples out of many-a British geologist, familiar with the Bradford Clay and with the time-name 'Bradfordian', proposed by Desor in 1859 , would not be likely to understand or to sympathize with a modern American proposal to apply the same term to some Lower Carboniferous beds in New York. Again, a French or German geologist who has been taught that the term 'Stonesfield slate' denotes certain ' schistes jurassiques inférieures d'Angleterre', runs the risk of being considerably misled when, in a recent memoir on the geology of Jura and the surrounding districts, he comes upon the term 'Stonefield schists' applied to some metamorphic rocks of considerably greater age.

Now, Sir, the object of this letter is not merely to indulge my lore for a grumble, but to suggest to the geologists of Britain, at any rate, two ways by which they might help themselves and others.

A paper recently issued by an American colleague states that certain formational names therein proposed have previously been submitted to an official committee on Geological Nomenclature, and have received its approval. Would it not be possible to have such a committee in this country, nominated, perhaps, by the Geological Survey and the Geological Society? The decrees of a committee, however authoritative, could have no binding force, but its existence might act as a deterrent to the irresponsible and as an aid to the conscientious worker. It would be the business of the committee to make itself familiar with the names already proposed in this and other countries, and to prevent such sources of confusion as the two mentioned above.

The second suggestion is that every British geologist who proposes a new name, whether it be in a memoir of the Geological Survey, in the Quarterly Journal of the Geological Society, or in the Proceedings of the Little Muddleborough Field Club, should be invited to send the 
ntme, together with a definition, to the Editor of the Geological Magazine. These names might be combined into a single list at the end of each year, or possibly published at more frequent intervals, according to the discretion of the Editor. It may, perhaps, be pointed out to me that, since the International Catalogue of Scientific Literature has a section for Geology, that would be the proper place for indexing such names. Agreed! But all the same the suggestion is not a practical one so long as that particular volume of the International Catalogue is thrown together (one cannot say 'edited') on its present lines.

These proposals are the best that occur to me at present. Should they give rise to any discussion and to any better proposals, I shall be glad; but whatever be the upshot of discussion I wish to insist that it is really time for something to be done.

F. A. Bather.

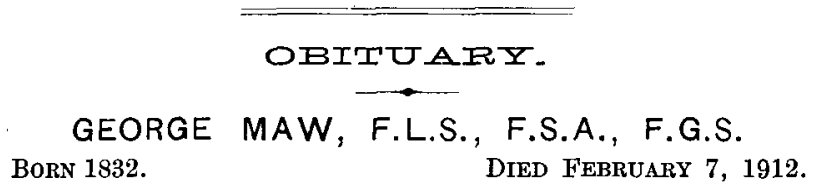

THE death is announced of George Maw, at Benthall, Kenley, Surrey, and formerly of Benthall Hall, Broseley, Shropshire, aged 79. Mr. Maw, who for many years was a manufacturer of encaustic tiles at Broseley, took an early interest in geology, became a Fellow of the Geological Society in 1864, and a valued contributor to the pages of the Geological Magazine, from the first volume in 1864 to 1878 .

His first communication, read before the Geological Society in 1864 , was on the drift-deposits of the Valley of the Severn, and it was followed by one on the potter's clay of Fremington near Barnstaple, a deposit which Maw was disposed to regard as of Glacial age. In 1865 he described in the Geological Magazine some deposits of Chert, White Sand, and White Clay, which occurred in pockets in the mountain-limestone of Llandudno. In 1867 he brought before the Geological Society observations "On the Sources of the Materials composing the White Clays of the Lower Tertiaries", and in the following year a paper "On the Disposition of Iron in variegated Strata", illustrated by coloured plates and many diagrams and analyses. This undoubtedly was his most important contribution to geological science, and arrested the attention and won the warmly expressed admiration of Professor Ruskin, who was enchanted with the beauty of coloration and rariegation in arrangement and banding displayed in the sections illustrating this very valuable work.'

In 1876 he published in the third edition of the Catalogue of Specimens of British Pottery and Porcelain in the Museum of Practical Geology, an instructive and practical appendix on a series of specimens which he had collected in order to illustrate the Clays and Plastic Strata of Great Britain.

1 See Quart. Journ. Geol. Soc., vol, xxiv, pp. 351-400, pls. $x i-x v$, and 24 woodeuts, 1868 . 